\title{
Implementation of Mechanical Technology Competence Learning Model with Maximum Likelihood Estimation
}

\author{
A. Muhammad Idkhan ${ }^{\# 1}$, Djuanda ${ }^{\# 2}$, Iswahyudi Indra Putra ${ }^{*}$

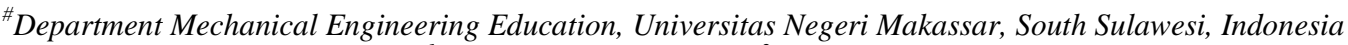 \\ E-mail: 'amuhidkhan@unm.ac.id; ${ }^{2}$ djuanda@unm.ac.id \\ *Department Technology and Vocational Education, Universitas Negeri Makassar, South Sulawesi, Indonesia \\ E-mail: iswahyudi2510@gmail.com
}

\begin{abstract}
Developed countries in the world need evaluation in the world of education. This evaluation is used to formulate policies that support the creation of competitive human resources against the industrial era 4.0. This research conducted to analyze and look at the mechanical, technological competencies of students who are influenced by factors of learning psychology, namely the scientific approach to learning, the level of student independence and the reasoning abilities of students. This study will use a non-probability sampling technique, namely accidental sampling technique. This method is a sampling procedure that selects samples from people or units that are most easily found or accessed as respondents. It is undoubtedly by the size of the sample in the Structural Equation Model with the estimation model using a minimum Maximum Likelihood (ML). The population of this research is the tenth-grade students in the Mechanical Engineering expertise program which consists of the Field of Mechanical Engineering and Welding Techniques in the Vocational High School in Makassar City, amounting to 248 students. The number of samples used was 120 respondents considering the outlier numbers at the period of the examination. The exogenous variable in this study is the implementation of the scientific approach, learning independence. The endogenous variable in this study is the achievement of mechanical technology competencies while the intervening variable or connecting variable is reasoning ability. From the consequences of the analysis, there is a significant influence between the variable ability to mechanical technology competence and the variable self-regulated learning to mechanical technology competence. It shows that students mandate learning, either directly or indirectly, will improve student competence but must be through understanding students' ethical reasoning. From the results of the study, there is a significant influence between the variable ability to mechanical technology competence and the variable selfregulated learning to mechanical technology competence. It shows that students mandate learning, either directly or indirectly, will improve student competence but must be through understanding students' ethical reasoning.
\end{abstract}

Keywords - evaluation education; scientific approach; reasoning; self-regulated learning; structural equation model analysis.

\section{INTRODUCTION}

Education is the most crucial thing in a nation, the development of a nation cannot be separated from the role of education, where through education a nation can produce reliable and expert human resources in various fields, reliable human resources can contribute positively to the sustainability of the economy and the progress of the nation [1]. The government plays a vital role in the continuity of education, where the government as a facilitator facilitates the community with adequate access to education, both in the form of learning resources, facilities, and infrastructure, educators who are experts in their fields, so that education can reach all levels of society [2].

Global education plays a significant role in improving the quality of human resources. Quality human resources are expected to be able to compete during the era of globalization. The era of globalization brings new challenges that must be answered by education. Global changes require changes in the management of life and society, including in the field of education. The concept of global education emphasizes whole ways of thinking if not just want to expand information about global linkages. With global education, it is expected that the quality of human resources would increase. Education is no longer teacher-centered but is student-centered. So that the output of education will be improved and able to compete amid the era of globalization.

The ability of students to explore and understand the learning material taught by teachers is an important thing to achieve maximum learning goals and quality [3]. A learning activity will end in vain if the students are not able to understand and master the subject matter taught. In the era of globalization which is increasingly advanced and developing 
today, especially in the field of education students are required to have quality human resources so that later they can compete in life during an increasingly advanced era. Therefore, in the field of education needs to be considered in the implementation of quality and efficient learning activities by a teacher in delivering material to students so that students can quickly receive and understand teaching material.

From the data from Education for All Global Monitoring Report of UNESCO [4], Indonesian education is lagging neighboring countries in ASEAN. In 2011, Indonesia's 127 Education Development Index (EDI) was 69th. The position of Indonesia is lagging compared to Malaysia in position 65 or Brunei which is in position 34, and Education products have not produced graduates who can think critically equal to the abilities of other peoples' children even though education is the main instrument of generation [5], [6].

Many problems will arise when students have practiced where students must think quickly to be able to solve the problems faced during practice so that the work done can be completed according to the time specified. That is what causes science-based experiments to be a field of scientific approaches with specific objectives and rules, where the main goal is to provide strong skills with a realistic theoretical basis for the phenomena we will observe. When a problem that is to observed raises questions that cannot answer, the scientific experiment method should be able to provide answers through logical processes, the process of learning experimental approaches is essentially a process of scientific thinking to prove hypotheses with logical thinking.

The ability of students to learn is the skill of a student, who has the results of what has learned that can show or seen through the results of learning [7]. There are three domains (aspects) that are related to students' abilities in learning, namely the cognitive domain (knowledge), the affective domain (attitude), and the psychomotor domain (skills) [8], [9]. The cognitive domain is the ability of students to analyze a problem based on their understanding. Affective domains are students able to determine the attitude to accept or reject an object. Psychomotor domains are students able to express well. Every student is said to be successful in learning if he can learn as stated above. However, the problem is that not all students have the same ability. Many factors influence students' ability to learn, including internal factors, external factors, and learning approach factors.

The process of learning mechanical technology is very complex, meaning that in the learning process it involves many elements, not only teachers and students but also technical and non-technical elements considered. However, the reality in the field to improve reasoning skills is not easy; this is because most teachers still teach in the usual way so that the learning process still focused on the instructor and lack of innovative learning [10]. Creating learning that is innovative, quality, fun, and focused on students following the level of ability of students is vital; one of them is by applying a scientific approach. So that by implementing a scientific approach in learning mechanical technology, it is expected to overcome student problems in improving their reasoning abilities [11]. Besides this, learning with a scientific approach can also foster student independence.
The scientific approach is part of a student-centered learning system and encourages active participation from students. The scientific method aims to provide understanding to students in identifying and explanation various materials using logical methods; data can come from anyplace, anytime and do not depend on direction information from the trainer. The application of a scientific approach to school learning aims to familiarize students with thinking, acting, and working using clear rules and steps [12]. The learning process becomes more critical than learning outcomes [13]. Learning with a logical method is learning that consists of observing, formulating questions and formulating hypotheses, gathering information with various methods, processing information and sketching decisions and communicating conclusions as well as other findings outside the problem formulation to obtain learning, competences, and manners.

The ability of reasoning is the goal to be achieved in each learning process both through formal and non-formal education, as well as in learning mechanical technology. Developing a reasoning process is needed because learning mechanical technology requires a search process of knowledge that is more specific to reasoning because in addition to the theories given later students will face with the process of working directly on practical learning, which requires students to be able to understand the use of tools and equipment more quickly. Work, students are required to be able to understand the processes of work safety when conducting practical learning activities.

Data from the Trends in the International Math and Science Survey in 2007 [14], it mentioned that only 5\% of Indonesian students could work on advanced categories that needed seasoning. In another perspective, $78 \%$ of Indonesian students could only work on low category questions which merely required knowing or memorizing. It is where the need to develop a curriculum that requires mastery of reasoning.

Self-Regulated learning will be able to make students better prepared to face various problems faced when the learning process carried out because students have high motivation and willingness to understand and understand the learning given by the instructor and make students more active in asking and answering questions given by the instructor [15]. Therefore, learning mechanical technology cannot be underestimated by students should be directed to help students learn. In learning mechanical technology, learning independence and reasoning skills needed. Students who are independent and have high reasoning will easily understand and master the lesson well. Mechanical technology lessons that require learning independence and reasoning skills to be able to master learning competencies with satisfying results.

Based on this, there is no other word for teachers to continue to improve their competencies, including in terms of applying the scientific approach to learning. The instructor is a learning manager. He is a thoroughly learning controller. The flow of learning depends on the "concoction" of the learning strategies it designs. This research was conducted to analyze the dominant factors, namely the implementation of the scientific approach, learning 
independence, and reasoning ability in influencing mechanical technology competencies.

\section{MATERIAL AND METHODS}

\section{A. Research Approach}

Every research usually uses approaches and methods. The approaches and methods used usually to refer to the construction of the problem, the purpose of the study, and the examination hypothesis. In this study, the approach used is a quantitative approach. This approach relies more on numbers in the form of scores as a basic framework of analysis. The score obtained by the survey method. This method, according to [16], is commonly used in huge and slight populations, but the data studied is data from samples taken from the population, so that related affairs, allocation, and relationships between variables found. In this case, the survey is intended to study attitudes, beliefs, values, demographics, behavior, opinions, habits, desires, ideas and other types of information [17], which needed for research purposes. From the data, facts or information obtained through the survey can describe the condition of each variable studied so that it is possible to know the influence of one variable with another variable, which in the context of this study the independent variable on the dependent variable.

\section{B. Respondents}

The respondents of this research are the tenth-grade students in the Mechanical Engineering expertise program which consists of the Field of Mechanical Engineering and Welding Techniques in the Vocational High School in Makassar City, amounting to 248 students. This method is a sampling procedure that selects samples from people or units that are most easily found or accessed as respondents. It is undoubtedly by the size of the sample in SEM with the estimation model using a minimum Maximum Likelihood (ML) which is required 100 samples [18]. Regarding the minimum sample size with SEM analysis, according to [19], states that if the model analyzed there are 5 (five) constructs or less where each construct measured by at least 3 (three) indicators, a minimum sample size of 100 - 300 observations. Hair [20], recommends the minimum number of samples is 5 - $10 \mathrm{x}$ the number of constructs (indicators) in this study as many as 11 constructs, which means the number of samples used is 110 respondents. From this, the number of samples used was 120 respondents considering the outlier numbers at the period of the examination.

\section{Data Collection}

The questionnaire is a technique of data collection conducted by providing a set of forms or written statements to obtain information from several respondents. This study uses a form of a directly closed questionnaire designed in such a way as to obtain data about the conditions experienced by respondents; then all alternative answers are listed in the questionnaire so that respondents choose one of the appropriate answers. Instruments gave to respondents using the Likert scale technique 5 points to measure research variables. Respondents will later choose answers from positive statements with five alternative answers available, namely from "strongly agree," "agree," "doubt," "disagree" and "strongly disagree."

\section{Research Design}

This research was conducted to determine how much influence and contribution of exogenous variables on endogenous variables. The exogenous variable in this study is the implementation of the scientific approach (X1), learning independence (X2). The endogenous variable in this study is the achievement of mechanical technology competencies (Y) while the intervening variable or connecting variable is reasoning ability $(\mathrm{Z})$. The relationship between exogenous and endogenous variables shown in the following figure:

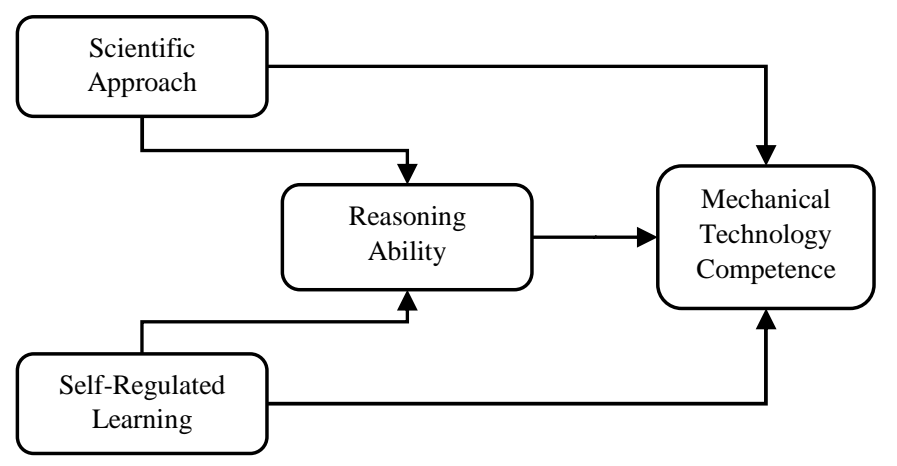

Fig. 1. Research Design Mechanical Technology Competence

The research design in Figure 1 takes the form of a structural model which is part of the SEM model shows the correlation between latent variables in the research model [21]. The testing of the structural model aims to find out what kind of relationship exists in the part of the variables that build the model rather than to make a new theoretical model [22].

\section{E. Data Analysis}

By looking at the theoretical framework, the data analysis method used in this investigation is quantitative examination using Structural Equation Modeling can describe as an analysis that combines the approach of factor analysis, structural model, and path analysis [23]. According to Hair [20], Structural Equation Modeling is a combination of separate statistical methods, namely factor analysis, and simultaneous equation models. This study uses a multivariate Structural Equation Model (SEM) technique, based on the consideration that SEM can combine measurement models and structural models simultaneously when compared to other multivariate techniques - having the ability to test direct and indirect influences (direct and indirect) [18]. The software used to process this data is IBM AMOS 22.

\section{RESULT AND DISCUSSION}

\section{A. The goodness of Fit (GOF)}

Some researchers then gave their views on the size of the model fit that needed to reported. Garson [19], it suggested to only description CMIN, RMSEA, one from baseline fit (NFI, CFI, TLI, IFI, RFI,), one from parsimony fit (PCFI, 
PNFI), and one from CAIC, BIC, AIC, ECVI, BCC, MECVI. Unlike Gefen [24], which only recommends reporting Chisquare, GFI, AGFI, SRMR, RMSEA, CFI, TLI, and RNI. Schumacher and Lomax [25], recommend only reporting RMSEA, CFI, and GFI. Kline [26], recommends only reporting Chi-square, df, Probability, CFI, RMSEA, and SRMR. Boomsma [27], recommends only reporting Chisquare, CFI, RMSEA, and SRMR. There are three types of measures in goodness-of-fit as follows:

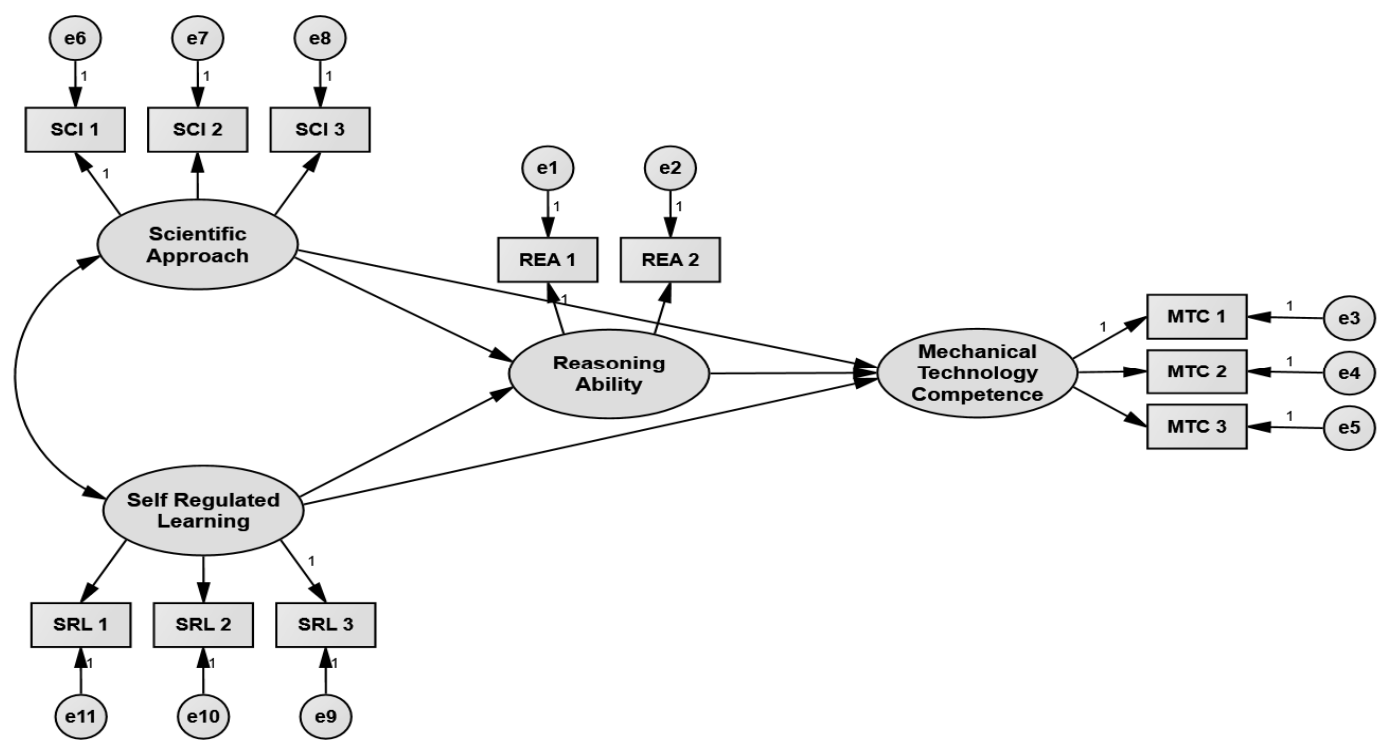

Fig. 2. Output Research Design Structural Equation Model with IBM AMOS

TABLE I

THE GOODNESS OF FIT (GOF) CRITERIA

\begin{tabular}{|c|l|r|r|r|r|}
\hline No. & Criteria & Value & Limit Value & Result & Source \\
\hline 1 & Absolute fit measures & & & & \\
\hline & Chi-Square $\left(X^{2}\right)$ & 0.812 & $\geq 0.050$ & Fit & {$[18],[28],[29]$} \\
\hline & Normal Chi-Square (CMIN/DF) & 0.891 & $\leq 2.000$ & Fit & {$[25],[30],[31]$} \\
\hline & Goodness of Fit Indices (GFI) & 0.931 & $\geq 0.900$ & Fit & {$[25],[28],[32]$} \\
\hline & Root Mean Square Error of Approximation (RMSEA) & 0.000 & $\leq 0.080$ & Fit & {$[25],[33]-[37]$} \\
\hline 2 & Incremental Fit Indices & & & & \\
\hline & Tucker Lewis Index (TLI) & 1.018 & $\geq 0.900$ & Fit & {$[25],[38],[39]$} \\
\hline & Comparative Fit Index (CFI) & 1.007 & $\geq 0.900$ & Fit & {$[37],[40],[41]$} \\
\hline & Incremental Fit Index (IFI) & 1.012 & $\geq 0.900$ & Fit & \\
\hline 3 & Parsimonious Fit Indices & & & & \\
\hline & Parsimony Normed Fit Indices (PNFI) & 0.614 & $\geq 0.500$ & Fit & \\
\hline & Parsimony Comparative Fit Indices (PCFI) & 0.639 & $\geq 0.500$ & Fit & {$[43],[44]$} \\
\hline
\end{tabular}

TABLE II

LOADING FACTOR Estimate, COMPOSITE RELIABILITy (CR), AND AVERAGE VARIANCE EXTRACTED (AVE)

\begin{tabular}{|c|c|c|c|c|}
\hline Variable Latent & Construct (Indicator) & Estimate & C.R & AVE \\
\hline \multirow[t]{3}{*}{ Scientific Approach } & Submission of competencies and plan (SCI 1) & 0.739 & 0.706 & 0.835 \\
\hline & Application of educational strategies (SCI 2) & 0.693 & & \\
\hline & Application of scientific approach (SCI 3) & 0.685 & & \\
\hline \multirow[t]{3}{*}{ Self-Regulated Learning } & Metacognitive (SRL 1) & 0.661 & 0.703 & 0.833 \\
\hline & Motivation (SRL 2) & 0.759 & & \\
\hline & Behavior (SRL 3) & 0.690 & & \\
\hline \multirow[t]{2}{*}{ Reasoning Ability } & Inductive reasoning (REA 1) & 0.727 & 0.761 & 0.829 \\
\hline & Deductive reasoning (REA 2) & 0.795 & & \\
\hline \multirow[t]{3}{*}{ Mechanical Technology Competence } & Work safety (MTC 1) & 0.603 & 0.723 & 0.850 \\
\hline & Measurement technique (MTC 2) & 0.758 & & \\
\hline & Material knowledge (MTC 3) & 0.809 & & \\
\hline
\end{tabular}

Evaluation of the Goodness of Fit criteria is an evaluation of the feasibility test of a model with several indexes and cut-off valuation criteria, to determine whether a model can be accepted or rejected [45]. As seen in Table 1, the criteria 
for Goodness of Fit have met the requirements, which means the model is structurally fit and can use for further analysis.

Each latent variable must be able to explain the indicator variance of at least $50 \%$. Therefore, the absolute correlation between latent variables and indicators must be $>0.70$ (absolute value of factor loadings) [46]. Reflective indicators should be removed from the measurement model if they have a value of factor loadings below 0.40 [21]. As seen in Table 2, the value of the loading factor in the measurement model is quite good, but some values have not passed the recommended value which means that only a few constructs (indicators) can explain the correlation between latent variables. The correlation value can see from the value of the loading factor $>0.7$. Then the reflective indicator value on the structural model is entirely above the required value which means there is no need for constructs from the latent variables that omitted.

The measurement model is assessed using reliability and validity. For reliability, Cronbach's Alpha can use. This value reflects the reliability of all indicators in the model. The minimum value of 0.70 is ideal and is 0.80 or 0.90 . In addition to Cronbach's Alpha, the composite reliability value that interpreted is the same as the Cronbach's Alpha value [46]. As seen in Table 2, the C.R value obtained from the results of SEM analysis on the measurement model > 0.7, which means the reliability of all models is quite good, and the model can use.

This Average Variance Extracted (AVE) value describes adequate convergent validity which means that a latent variable can explain more than half of the variants of the construct on average. The minimum recommended AVE value is 0.50 [47]. Table 2 shows good results with the AVE value obtained if averaged at 0.84 , which means that the validity value of the structural model made has been very good.

From the measurement model described in Table 3, the results of the Structural Equation Model with AMOS Program are as follows:

TABLE III

STANDARDIZED REGRESSION WEIGHT

\begin{tabular}{|rrl|r|r|r|r|}
\hline & & Estimate & S.E. & C.R. & P \\
\hline Reasoning Ability & $\leftarrow$ & Scientific Approach & 0.370 & 0.536 & 0.690 & 1.621 \\
\hline Mechanical Technology Competence & $\leftarrow$ & Scientific Approach & 0.365 & 0.383 & 0.953 & 1.126 \\
\hline Reasoning Ability & $\leftarrow$ & Self-Regulated Learning & 0.184 & 0.252 & 0.730 & 1.318 \\
\hline Mechanical Technology Competence & $\leftarrow$ & Self-Regulated Learning & 0.606 & 0.221 & 2.742 & 0.008 \\
\hline Mechanical Technology Competence & $\leftarrow$ & Reasoning Ability & 0.736 & 0.235 & 3.132 & 0.000 \\
\hline
\end{tabular}

\section{B. Relationship Between Variables}

According to George \& Mallery [48], a relationship between variables can be said to have a significant effect if:

- Critical Ratio (C.R) value is higher than 2.56;

- A probability value (p) is smaller than 0.05

From the description; it can conclude that in the results of the Standardized Regression Weight obtained in Table 3, there are only two significant relationships, namely:

- Reasoning Ability to Mechanical Technology Competence

- Self-Regulated Learning to Mechanical Technology Competence

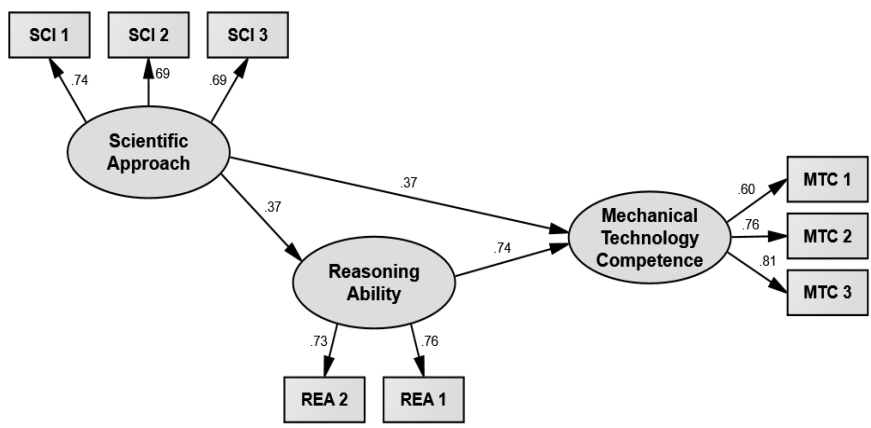

Fig. 3 Relations between Scientific Approach to Mechanical Technology Competence through Reasoning Ability.

The students were expected to be able to be critical and more active in the learning activities carried out. The reasoning process divided into two reasons, namely inductive reasoning and deductive reasoning. According to Arthur [49], inductive reasoning is a type of reasoning that starts from specific/singular questions, then general conclusions are drawn. While deductive reasoning can be a type of reasoning that starts from general questions, then conclusions are specific/individual are drawn.

The scientific approach is closely related to three learning theories, namely the theory of Bruner, Piaget, and Vygotsky. In Bruner's learning theory or often called discovery learning theory, there are four most important things related to learning theory. First, someone only learns and develops ideas when he uses his mind. Second, by performing a cognitive development in the discovery process, scholars will gain a sense and intelligence that is intrinsic knowledge. Third, the only way for people to learn methods in making problem-solving is that they can make discoveries. Fourth, with someone making a discovery, it will make memory retention stronger. The four things above are compatible with the cognitive processes needed in learning using the logical method [50], [51]. Piaget's theory states that learning is related to the creation and expansion of schemes. The scheme, in this case, is a combination of mental or cognitive with which one can adapt and coordinate the situation around him [52].

Scientific approach is a studying method designed so that students actively build ideas, laws or values through stages of observing to identify or find problems, formulate problems, submit or formulate hypotheses, collect data with various methods, examine data, draw conclusions and communicate ideas, laws, or the principle that is "found". 
The Scientific approach is a European project that involves interdisciplinary collaboration between mathematics and science. It aims to develop learning towards comprehensive and multidimensional learning about mathematical content and concepts. The basic idea is to encourage mathematics learning in the scientific context and student activities. Then it is mentioned that this approach links mathematics with science, so students will interestingly learn mathematics. Learning by doing activities will contribute to the students' intuitive understanding of mathematics. In other words, learning useful mathematics is experiencing or acting [53]. In mathematics learning, the steps of the scientific approach consist of collecting data from experiments, developing and investigating a mathematical model in the form of different representations, and reflections.

In line with the outcomes of the research of Kramarski and Mizrachi [54], whose research was conducted on 86 class VII students. In this study found facts, students who often get learning with a metacognitive-self questioning (IMP) approach and given extensive opportunities to demonstrate their mathematical ideas, the achievement of mathematical reasoning abilities increases significantly

Copi [55], argues that reasoning is a unique form of thinking to conclude the conclusions described by the premise. Glass and Holyoak [56], say that reasoning is a conclusion of various current knowledge and beliefs. Galloti [57], the reasoning is transforming the information provided to examine conclusions. It can be said that reasoning is a person's thinking power in attracting and deducing things

According to Shurter and Pierce [58], the term reasoning is a translation of reasoning, a process to reach logical conclusions based on relevant facts and sources. Whereas according to Charlin [59], explain the reasoning as a thought process that attempts to connect facts that are known to lead to a conclusion in the form of knowledge. As an activity of thinking, reasoning has two characteristics, namely logical and analytical thinking. Logical thinking defined as the activity of thinking according to a particular pattern or logic with specific criteria of truth. The second characteristic is that analytical is a consequence of the existence of a specified pattern of thinking. An analysis is an activity of thinking based on specific steps.

Reasoning ability helps students to conclude and prove a statement, build new ideas, to solve problems. Therefore, mathematical reasoning skills must always be accustomed to and developed in every learning.

Baroody [60], explains that intuitive reasoning is reasoning that plays intuition so that it requires knowledge readiness. Conclusions obtained from what he thinks is right so that a deep understanding of knowledge plays a vital role in carrying out an intuitive reasoning process.

Piaget [52], states that the practice of thinking, formulating and solving problems and drawing conclusions will help students to develop their thinking or intelligence. Thus, the more students practice solving mathematical problems, the more they will understand and develop their thinking. According to Novick [61], reasoning plays a significant role in problem-solving. The ability to utilize known problems (fundamental or source) to new problems that have identical structures will improve the performance of problem-solving. Whereas according to Kaur et al. [62], that thinking processes (cognitive abilities) that can optimize mathematical problem-solving abilities are reasoning, communication, and mathematical connections.

Based on the results of several studies, there are still some problems encountered during learning related to weak mathematical reasoning and communication skills. Among other things, Hiebert [63], reported that in general students still use thinking based on memorization rather than doing reasoning processes in solving mathematical problems in the class. In the Lithner [64]-[66], an empirical study conducted in parallel reported, based on study analysis, the habit of using imitation thinking by students is the main factor behind the difficulty in understanding mathematical material. The results of similar studies from Boesen, Lithner, and Palm indicate that the difficulties in learning mathematics are mainly due to students still relying on superficial memorization and mathematical thinking and mathematical thinking like this is generally used by students in all groups age [67], [68].

Furthermore, in Hatzikiriakou's study, it was reported that based on studies relevant to deductive reasoning with the subjects of prospective mathematics teachers, consistently showed that reasoning competencies did not materialize in the context of learning. In general, people make many mistakes when solving abstract reasoning problems and they are not able to understand the difference between necessity and possibility. It could be a misunderstanding in interpreting a premise, so it is wrong to build a mental model or an inability to translate the conclusions of a premise. Problems can also arise because students not used to be involved in activities or experiences in solving reasoning questions [69].

Hung [70], suggested that in learning students should be motivated and guided by teachers to construct their ideas, concepts, and understanding of the material studied based on the prior knowledge they already have. Based on the opinions of the experts mentioned above, in expanding students' reasoning and numerical communication skills, constructivist-based learning is needed, namely learning that can engage student activities in a full and meaningful manner during learning.

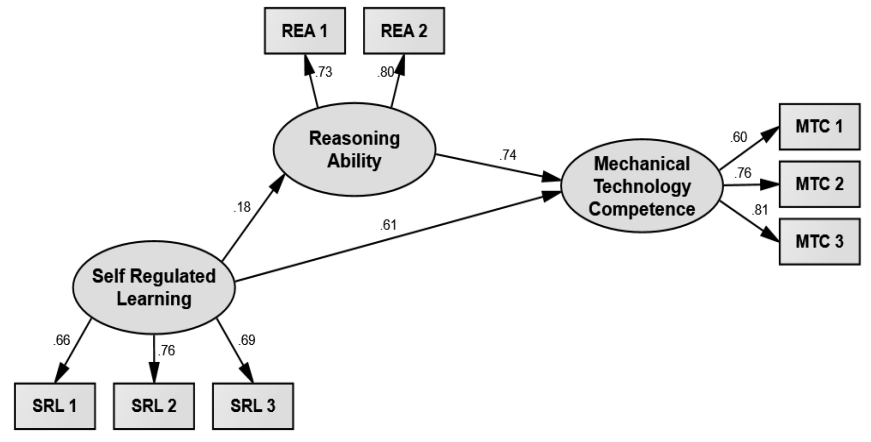

Fig. 4. Relations between Self-Regulated Learning to Mechanical Technology Competence through Reasoning Ability.

The outcomes of the research prove that the majority of the scholars remember the best things from being studied because of the actions they took, and they know the reasons. Someone remembers, for example, the math that students 
master because they must cut the length of the pipe to form a certain angle, or when a science student evaluates the mayor's policy to add fluoride to drinking water, they will remember the knowledge they learned. Active learning, also called "direct" learning, is learning that makes the lesson attached. Searching for and linking information actively from work, community, and classrooms, then using it for specific reasons will embed that information in memory [71].

In Vygotsky's theory, he explains that learning happens when students work or handle tasks that have not been studied but are still in their capacity and the job is still in the area of proximal growth between the level of development of students. This activity defined as problem-solving skills under the guidance of more capable adults or peers [72], [73].

Dale Parnell assures us that independent learning can make students successful. He shows strong evidence about the progress of students in this learning [74]. Independent learning can be successful because, as we see, it is natural for children to act independently and make their own decisions. It is also natural for children to find connections between new ideas and their situations. All humans, always aware of their environment, and adjust their thoughts and actions to respond.

Made based on the principle of self-regulation, every living being is independent and self-regulating. Therefore, every creature has consciousness. This awareness, as a unique identity of consciousness, can cause a single cell to realize the existence of natural disturbances in its environment and can decide whether to react to it. If the cell reacts, the result can be a change that occurs little by little in the cell's physical structure. This awareness causes living creatures to pay attention and respond to their environment. As living things, we value our environment — family relationships, work, pressure from peers and schools - and we make choices that describe our potential. In other words, we choose what we want to be later. We may choose to react in ways that encourage growth and development, or it may not.

To be successful, independent students must be able to ask interesting questions. Amazement is the forerunner of creativity, and sharp questions can perfect beliefs and explain events. "To be able to understand, students must look for a meaning" To look for meaning, students must have the opportunity to form and ask questions [75]. Selfregulated learning can regulate learning performance and achievement. Self-regulated learning is vital to study, considering students must organize themselves so that their learning achievements are as expected. That one component of self-regulated learning, namely regulating business Wolter et al., [76], which has a relationship with achievement and refers to the intention of students to get resources, energy, and time to be able to complete learning tasks important. In addition to self-regulated learning, learning achievement will be achieved by its objectives also based on interests.

Independent students are flexible. They do not do anything just once. Often, they make a list that must be done then see what they have done and assess their work [76][78]. Also, a student who independently organizes the learning process by observing whether he can do it, then comparing it to a standard and making judgments about the quality of its performance, finally making plans for what to do next.

Self-regulated learning places the importance of one's ability to learn discipline in regulating and controlling oneself, especially when facing difficult tasks. On the other hand, self-regulated learning emphasizes the importance of the initiative, because self-regulated learning is a learning process that occurs because of the initiative.

Self-regulated learning refers to the planning and monitoring of cognitive and affective processes that can help in completing academic tasks to get good results. Selfregulated learning can be said to be high if the person can determine the strategies that will be used to remember, study, solve problems and think and run processes [76] have high self-efficacy [78], can seek help according to their needs [79].

Self-learning gives students exceptional chances to improve their consciousness of their environment. Selflearning allows scholars to make constructive selections about how they will cope with concern and disorder in everyday life. This design will enable students to act on their inventiveness to shape the atmosphere. In this way, independent students develop their potential. They discover their new interests and hidden talents while developing to achieve academic excellence. They also found that they were able to influence their environment. Through the process of independent learning, they learn that they can become cocreators in their world of residence. They realize that it is their responsibility to re-create a world where every living creature will feel at home.

Learning achievement can be achieved if students have an interest in learning about all subjects, trying to improve themselves by practicing to sharpen students' memories and be able to understand what they taught. Learning which means it is more comfortable and longer to remember that learning which seems meaningless. So there needs to be an impression that is pleasant, interesting, reducing tension, useful or enriching knowledge more efficiently and stored longer in memory so that it can lead to an interest in learning.

Butler [80], argues that learning independence is a cycle of repetitive cognitive activities in the form of analyzing tasks, choosing, adopting, or finding a strategic approach to achieve task objectives, and monitoring the results of strategies that have implemented.

Rochester Institute of Technology [81], identifies several characteristics of learning independence, namely: choosing learning goals, seeing difficulties as challenges, choosing and using available resources, collaborating with other individuals, building meaning, understanding the achievement of success is not enough just by effort and ability but must be accompanied by self-control.

\section{CONCLUSIONS}

The learning model needed is one that can produce the ability to learn, not only is it acquired several pieces of knowledge, skills, and attitudes, but more important is how students obtain these abilities. From the results of research conducted that there is a tendency for the dominant influence of independent learning by students to have a significant effect on improving competence. In independent learning, students have a type such as "self-regulation" - self- 
government. They make their own decisions and accept responsibility for that. In other words, students organize themselves to, adjust their actions to achieve individual interests or goals. Independent learning is a process. As with other processes, this learning pattern follows several procedures to achieve one goal. The independent learning process is a method that involves students in action that includes several steps and produces both visible and invisible results. These steps use various skills that have been written before, also using academic knowledge.

\section{REFERENCES}

[1] A. Green, "Education, globalization and the nation state," in Education, Globalization and the Nation State, Springer, 1997, pp. $130-186$.

[2] M. Friedman, The role of government in education, vol. 13. Rutgers University Press New Brunswick, NJ, 1955.

[3] W. E. Deming, The new economics for industry, government, education. MIT press, 2018.

[4] United Nations Educational, Scientific and Cultural Organization (UNESCO)., "Education for All Global Monitoring Report 2010: Reaching the Marginalized," 2010.

[5] E. Unterhalter, Measuring gender inequality in education in South Asia. Citeseer, 2006.

[6] United Nations Educational, Scientific and Cultural Organization (UNESCO)., Education for All Global Monitoring Report 2008: Education for All by 2015. Will We Make It? Oxford University Press, 2007.

[7] J. Hattie, J. Biggs, and N. Purdie, "Effects of learning skills interventions on student learning: A meta-analysis," Rev. Educ. Res., vol. 66, no. 2, pp. 99-136, 1996.

[8] E. J. Simpson, "The Classification of Educational Objectives, Psychomotor Domain.," 1966.

[9] T. C. Reeves, "How do you know they are learning? The importance of alignment in higher education," Int. J. Learn. Technol., vol. 2, no. 4, pp. 294-309, 2006.

[10] R. W. Bybee, Achieving scientific literacy: From purposes to practices. ERIC, 1997.

[11] F. Reif, "Teaching problem solving-A scientific approach," Phys. Teach., vol. 19, no. 5, pp. 310-316, 1981.

[12] N. R. Council, Advancing scientific research in education. National Academies Press, 2004.

[13] L. Ivanitskaya, D. Clark, G. Montgomery, and R. Primeau, "Interdisciplinary learning: Process and outcomes," Innov. High. Educ., vol. 27, no. 2, pp. 95-111, 2002.

[14] National Center for Education Statistics (NCES), "Trends in International Maths and Science Survey (TIMSS) 2007," U.S. Department of Education (https://www.ed.gov/), 2007. [Online]. Available: $\quad$ https://nces.ed.gov/timss/results07_science07.asp. [Accessed: 05-Apr-2019].

[15] P. C. Blumenfeld, E. Soloway, R. W. Marx, J. S. Krajcik, M. Guzdial, and A. Palincsar, "Motivating project-based learning: Sustaining the doing, supporting the learning," Educ. Psychol., vol. 26, no. 3-4, pp. 369-398, 1991.

[16] F. N. Kerlinger and H. B. Lee, Foundations of Behavioral Research, 4th ed. New York: Holt, Rinehart and Winston, 2000.

[17] S. Schumacher and J. H. McMillan, Research in Education Evidence-Based Inquiry. Boston: Pearson Education, 2006.

[18] G. D. Garson, Partial Least Squares: Regression \& structural equation modeling. Asheboro, USA: Statistical Publishing Associates, 2016.

[19] G. D. Garson, Structural Equation Modeling, Blue Book. Asheboro, North Corolina: Statistical Associates Publishing, 2012.

[20] J. F. Hair, W. C. Black, B. J. Babin, and R. E. Anderson, Multivariate Data Analysis, 7th ed. Harlow, England: Pearson New International Edition, 2014.

[21] R. H. Hoyle, Structural Equation Modeling : Concepts, Issues, and Applications. Thousand Oaks, California: SAGE Publications, Inc., 1995.

[22] A. H. Hasim, L. B. Said, and S. M. Hafram, "Have a Personal Vehicle: Is it really need or simply want ?," vol. 1, no. 1, pp. 7-16, 2019.
[23] B. M. Byrne, Structural equation modeling with AMOS: Basic concepts, applications, and programming, 2nd ed. New York: Routledge, 2016.

[24] D. Gefen, E. E. Rigdon, and D. Straub, "Editor's comments: an update and extension to SEM guidelines for administrative and social science research," Mis Q., pp. iii-xiv, 2011.

[25] R. E. Schumacher and R. G. Lomax, A Beginner's Guide to Structural Equation Modeling: Third Edition, 3rd ed. Mahwah, NJ: Lawrence Erlbaum Associates, 2010.

[26] R. B. Kline, "Promise and pitfalls of structural equation modeling in gifted research.," 2010.

[27] A. Boomsma, "Reporting analyses of covariance structures," Struct. Equ. Model., vol. 7, no. 3, pp. 461-483, 2000.

[28] K. G. Jöreskog and D. Sörbom, LISREL 8: Structural equation modeling with the SIMPLIS command language. Scientific Software International, 1993.

[29] J. J. Hox and T. M. Bechger, "An introduction to structural equation modeling," 2007.

[30] B. Wheaton, B. Muthen, D. F. Alwin, and G. F. Summers, "Assessing reliability and stability in panel models," Sociol. Methodol., vol. 8, pp. 84-136, 1977.

[31] E. G. Carmines, "Analyzing models with unobserved variables," Soc. Meas. Curr. issues, vol. 80, 1981.

[32] J. S. Tanaka and G. J. Huba, "A general coefficient of determination for covariance structure models under arbitrary GLS estimation," $B r$. J. Math. Stat. Psychol., vol. 42, no. 2, pp. 233-239, 1989.

[33] J. H. Steiger and J. C. Lind, "Statistically based tests for the number of common factors," in Paper presented at the annual meeting of the Psychometric Society, May 1980, 1980.

[34] M. W. Browne and R. Cudeck, "Alternative ways of assessing model fit," Sage Focus Ed., vol. 154, p. 136, 1993.

[35] L. J. Williams and E. O'Boyle Jr, "The myth of global fit indices and alternatives for assessing latent variable relations," Organ. Res. Methods, vol. 14, no. 2, pp. 350-369, 2011.

[36] F. Chen, P. J. Curran, K. A. Bollen, J. Kirby, and P. Paxton, "An empirical evaluation of the use of fixed cutoff points in RMSEA test statistic in structural equation models," Sociol. Methods Res., vol. 36, no. 4, pp. 462-494, 2008.

[37] L. Hu and P. M. Bentler, "Cutoff criteria for fit indexes in covariance structure analysis: Conventional criteria versus new alternatives," Struct. Equ. Model. a Multidiscip. J., vol. 6, no. 1, pp. 1-55, 1999.

[38] L. R. Tucker and C. Lewis, "A reliability coefficient for maximum likelihood factor analysis," Psychometrika, vol. 38, no. 1, pp. 1-10, 1973.

[39] P. M. Bentler and L. T. Hu, "Evaluating model fit," in Structural equation modeling: Concepts, issues, and applications, Thousand Oaks, CA: SAGE Publications, 1995, pp. 76-99.

[40] P. M. Bentler, "SEM with simplicity and accuracy," J. Consum. Psychol., vol. 20, no. 2, pp. 215-220, 2010.

[41] T. A. Brown, Confirmatory factor analysis for applied research New York: Guilford Publications, 2014.

[42] K. A. Bollen, "A new incremental fit index for general structural equation models," Sociol. Methods Res., vol. 17, no. 3, pp. 303-316, 1989.

[43] L. James, S. Mulaik, and J. M. Brett, Causal analysis: Assumptions, models, and data. Beverly Hills: Sage publications, 1982.

[44] C. C. DiClemente and J. O. Prochaska, "Self-change and therapy change of smoking behavior: A comparison of processes of change in cessation and maintenance," Addict. Behav., vol. 7, no. 2, pp. 133142, 1982.

[45] K. A. Bollen and J. S. Long, Testing structural equation models, vol. 154. Sage, 1993.

[46] M. S. Khine, L. C. Ping, and D. Cunningham, Application of Structural Equation Modeling in Educational Research and Practice : Contemporary Approaches to Research, 7th ed. Rotterdam, Netherlands: Sense Publishers, 2013.

[47] R. P. Bagozzi and Y. Yi, "On the evaluation of structural equation models," J. Acad. Mark. Sci., vol. 16, no. 1, pp. 74-94, 1988.

[48] D. George and P. Mallery, IBM SPSS Statistics 23 Step by Step: A Simple Guide and Reference, 14th ed. New York, United States: Routledge, 2016.

[49] W. B. Arthur, "Inductive reasoning and bounded rationality," Am. Econ. Rev., vol. 84, no. 2, pp. 406-411, 1994.

[50] R. B. Sund and A. A. Carin, "Teaching science through discovery," Ohio, O., Merrill, Co, 1975.

[51] J. S. Bruner, "The act of discovery," Harv. Educ. Rev., vol. 31, pp. 21-32, 1961 . 
[52] J. Piaget, "Piaget's theory," in Piaget and his school, Springer, 1976, pp. 11-23.

[53] R. Gersten et al., "Assisting Students Struggling with Mathematics: Response to Intervention (RtI) for Elementary and Middle Schools. NCEE 2009-4060.," What Work. Clear., 2009.

[54] B. Kramarski and N. Mizrachi, "Online discussion and self-regulated learning: Effects of instructional methods on mathematical literacy," J. Educ. Res., vol. 99, no. 4, pp. 218-231, 2006.

[55] I. M. Copi and K. Burgess-Jackson, Informal logic. Macmillan Publishing Company, 1991.

[56] A. L. Glass, K. J. Holyoak, and J. L. Santa, "Cognition Reading," MA Addison-Wesley, 1979.

[57] K. M. Galotti, "Approaches to studying formal and everyday reasoning.," Psychol. Bull., vol. 105, no. 3, p. 331, 1989.

[58] R. L. Shurter and J. R. Pierce, Critical Thinking. New York, United States: McGraw Hill Inc, 1966.

[59] B. Charlin, H. P. A. Boshuizen, E. J. Custers, and P. J. Feltovich, "Scripts and clinical reasoning," Med. Educ., vol. 41, no. 12, pp. 1178-1184, 2007.

[60] A. J. Baroody and R. T. Coslick, Problem solving, reasoning, and communicating, $K-8$ : Helping children think mathematically. Prentice Hall, 1993.

[61] L. R. Novick and K. M. Catley, "Reasoning about evolution's grand patterns: College students' understanding of the tree of life," Am. Educ. Res. J., vol. 50, no. 1, pp. 138-177, 2013.

[62] B. Kaur and T. L. Toh, Reasoning, Communication and Connections in Mathematics: Yearbook 2012, Association of Mathematics Educators, vol. 4. World Scientific, 2012.

[63] J. Hiebert and P. Lefevre, "Conceptual and procedural knowledge in mathematics: An introductory analysis," Concept. Proced. Knowl. case Math., vol. 2, pp. 1-27, 1986.

[64] J. Lithner, "Students' mathematical reasoning in university textbook exercises," Educ. Stud. Math., vol. 52, no. 1, pp. 29-55, 2003.

[65] J. Lithner, "Mathematical reasoning in calculus textbook exercises," J. Math. Behav., vol. 23, no. 4, pp. 405-427, 2004.

[66] J. Lithner, "Mathematical reasoning in task solving," Educ. Stud. Math., pp. 165-190, 2000.

[67] T. Palm, J. Boesen, and J. Lithner, "Mathematical reasoning requirements in Swedish upper secondary level assessments," Math. Think. Learn., vol. 13, no. 3, pp. 221-246, 2011.
[68] J. Boesen, J. Lithner, and T. Palm, "The relation between types of assessment tasks and the mathematical reasoning students use," Educ. Stud. Math., vol. 75, no. 1, pp. 89-105, 2010.

[69] K. Hatzikiriakou and P. Metallidou, "Teaching deductive reasoning to pre-service teachers: Promises and constraints," Int. J. Sci. Math. Educ., vol. 7, no. 1, pp. 81-101, 2009.

[70] M. Hung Cheng and K. Chee Pang, "Teacher socialization Implications for the design and management of initial teacher education programmes," Educ. Train., vol. 39, no. 5, pp. 195-204, 1997.

[71] J. Souders and C. Prescott, "A Case for Contextual Learning.," High Sch. Mag., vol. 7, no. 3, pp. 38-43, 1999.

[72] L. S. Vygotsky, The collected works of LS Vygotsky: Problems of the theory and history of psychology, vol. 3. Springer Science \& Business Media, 1997.

[73] L. Vygotsky, "Interaction between learning and development," Readings Dev. Child., vol. 23, no. 3, pp. 34-41, 1978.

[74] D. Parnell, Contextual Teaching Works!: Helping Students Reach Higher Levels of Achievement. CCI Pub., 2001.

[75] J. G. Brooks and M. G. Brooks, "In search of understanding," case Constr. classrooms, pp. 101-118, 1993.

[76] C. A. Wolters, "Regulation of motivation: Evaluating an underemphasized aspect of self-regulated learning," Educ. Psychol., vol. 38, no. 4, pp. 189-205, 2003.

[77] C. S. Carver and M. Scheier, Principles of self-regulation: Action and emotion. Guilford Press, 1990.

[78] B. J. Zimmerman, "A social cognitive view of self-regulated academic learning.," J. Educ. Psychol., vol. 81, no. 3, p. 329, 1989.

[79] S. A. Karabenick and R. Sharma, "Perceived teacher support of student questioning in the college classroom: Its relation to student characteristics and role in the classroom questioning process.," $J$. Educ. Psychol., vol. 86, no. 1, p. 90, 1994.

[80] D. L. Butler, "Individualizing instruction in self-regulated learning," Theory Pract., vol. 41, no. 2, pp. 81-92, 2002.

[81] R. Fasse, J. Humbert, and R. Rappold, "Rochester Institute of Technology: Analyzing student success.," J. Asynchronous Learn. Networks, vol. 13, no. 3, pp. 37-48, 2009. 